\title{
EFFECT OF INSPIRATIONAL MOTIVATION AND IDEALIZED INFLUENCE ON EMPLOYEE PERFORMANCE AT MOI TEACHING AND REFERRAL HOSPITAL, ELDORET, KENYA
}

\author{
Stanley Kulei Chebon* \\ Deputy Manager, Planning Monitoring and Evaluation \\ Moi Teaching and Referral Hospital \\ P.O. Box 3 - 30100, Eldoret, Kenya \\ Dr. Wilson Kipkirui Aruasa \\ Chief Executive Officer \\ Moi Teaching and Referral Hospital \\ Linus Kipkorir Chirchir \\ Senior Systems Administrator, \\ Moi Teaching and Referral Hospital
}

\begin{abstract}
Inspirational motivation and idealized influence are among the key components of transformational leadership. Inspirational motivation entails encouragement of followers to raise their consciousness about and elicit their commitment to the mission and vision. Idealized influence refers to the behaviours of a transformational leader that evoke in followers as sense of trust, admiration, respect and the desire to emulate the leader. The research investigated the influence of transformational leadership on employee performance deriving evidence from the Moi Teaching and Referral Hospital (MTRH) in Kenya. From the study, this paper examines the effect of inspirational motivation and idealized influence on employee performance. The research used a descriptive research design. It targeted a population of comprised 3,739 employees of MTRH (18 staff from top management; 110 employees from middle level management and 3611 employees from the operational level). The sampling frame used was the staff establishment dashboard for the Hospital. Stratified random sampling and simple random sampling methods were used in each of the stratum to recruit respondents to participate in the study. The sample size came to463 (17 from top management; 86 from middle management and 360 operational staff). On influence of inspirational motivation on employee performance, the study established that leaders motivated employees to high productivity through creativity and innovation and ensured that there is clear conveyance of messages across the organization. Supervisors also articulated a compelling vision for the future and talks enthusiastically about what needs to be accomplished. Further the study revealed that the leaders provided continual improvement, inspires confidence and shows determination to accomplish what he/she sets out to do. Regarding the influence of idealized influence on employee performance, employees were proud to be associated with the supervisors and performance requirements are designed according to the organization needs. The study also revealed that supervisors were also regarded as good role models in influencing high quality of service among employees and employees' participation in decision making is encouraged. The study concludes that leaders at the MTRH encourage high productivity through creativity and innovation as well as encourages staff to rethink ideas that had never been questioned. The study recommends that the leaders should continuously inspire their employees to enhance their performance and enable the organization achieve its goals and objectives.
\end{abstract}

Keywords: Inspirational Motivation, Idealized Influence, Employee Performance, Moi Teaching, Referral Hospital, MTRH

\section{Introduction}

Inspirational motivation is about encouraging subjects in order to elevate their consciousness of about the organization's mission, vision and committing to the vision is a key theme of this factor. The key indicators of inspirational motivation are organizational vision, communication, challenging to workers encouragement, working with workers, and giving autonomy are the core values of inspirational motivation (Barine \& Minja, 2014). Bass (1985) describes inspirational motivation as providing followers with challenges and meaning for engaging in shared goals. According to Kent, Crotts and Azziz (2001), inspirational motivation enables leaders to remain focused on the vision of the group despite any obstacles that may arise. 
Yukl (2010) identifies inspirational motivation behaviours as communicating an appealing vision, using symbols to focus subordinate effort, and modelling appropriate behaviours. Banjeriand Krishnan (2000) relate inspirational motivation to concepts of ethics, claiming that when leaders show concern for organizational vision and follower motivation, they are more inclined to make ethical decisions.

In inspiring their workforce, the management of an organization can build goodwill at the group level by creating an organizational culture that's friendly to employees. A worker-friendly organization can inspire both motivation and organizational loyalty. Appropriate leadership has the responsibility of enhancing inspiring motivation and enhancing job satisfaction. Productivity improvement requires and demands more than just decentralization, customer service, technology or renovation: the success of organizations will depend on inspiring employee motivation. Human resources are the only assets demanding generous nurturing (Salanova \& Kirmanen, 2010).

\section{Inspirational Motivation and Employee Performance}

Kehinde and Banjo (2014) did a test of the impact of leadership styles on employee performance, with a specific study of department of Petroleum Resources. The implication of their study was that "transformational leadership style" would bring effective results in organizations because it motivates employees to go beyond ordinary expectations, appeals to follower's higher order needs and moral values, generates the passion and commitment of followers for the mission and values of the organization, instils pride and faith in followers, communicates personal respect, stimulates subordinates intellectually, facilitates creative thinking and inspires followers to willingly accept challenging goals and a mission or vision of the future mission and objectives of organization, they recommend that transformational leadership style is good or appropriate for organizations that wish to compete successfully and mentor subordinates who will be managers of tomorrow to keep the flag flying for the firm.

Ndisya and Juma (2016) examined the application of components of transformational leadership at Safaricom. The study found a positive relationship between inspirational motivation and staff performance. Most respondents on average agreed with the presence of motivation to accomplish organizational goals and objectives, support for team building, leader's demonstration of the tasks employees should do, and assisting employees find meaning in their work. This means that the changes in the inspirational motivation had significant changes in employee performance such that when inspirational motivation increases, there would be a similar increase in employee performance. The study recommended that there is need on the organizational leadership to improve on its employees' response to improve service to the company.

Rajhans (2012) investigated the link between communication and motivation and its overall impact on the staff performance using an empirical review. The results showed that organizational communication plays an important role in employee motivation and performance of staff. The study recommended that there has to be upward and downward communication in an organization so that creative suggestions from the staff are used to assist management in decisionmaking and improvement of the company. Employees' performance is determined by ability and motivation. If employees do not have such good ability, then they will also not be able to perform well in their job. To improve employees' performance, a leader whose orientation is on changes and improvement on work environment, motivation, values, and patterns to improve overall organizational performance is needed (Crompton, 2012).

According to Gomes (2014), leaders have employed inspirational motivation to embolden and inspire people and stimulate them intellectually to back up followers' inventive and creative work. In a research carried out by Ahmad et al. (2014) to determine the effect of transformational leadership on employee motivation, it was found that inspirational motivation was positively correlated to employee motivation with the value of $r=.335, p<0.001$. However, the same study established that idealized influence had a greater positive effect on employee motivation with a correlation coefficient value, $r=.357$. Another study conducted by Elgelal (2014) to examine the impact of transformational leadership on employee performance determined that inspirational motivation was positively associated with employee motivation. Transformational leaders are able to draw a strict and positive perception of the future, for their juniors and encouraged them to push toward the goals and mission of the organization (Hayatiet al., 2014). Transformational leaders inspire the people by taking challenges and acting as their role models (Jandaghi, Martin \&Farjami, 2015). Transformational leadership allows leaders to clarify the meaning of challenges, which followers encounter and inspire them to achieve desired goals (Hayati, Charkhabi \& Naami, 2014).

Mpungu (2009), in a study to determine the effect of communication on the performance of workers in organizations with acase study being Mobile Telephone Network (MTN), both qualitative and quantitative methods were used in the study where a total of 86 respondents consisting of all the 23 managers, all the 11 heads of departments and 50 workers were sampled. 
The findings concluded that communication had a positive contribution to the performance of workers and therefore utilization of communication in a company was found to be having a positive impact on the staff performance. The study recommended that for organizations to be performing highly, effective communication that involve employees in decision making should be adopted and bureaucratic tendencies must be avoided, and that leaders should avail necessary information to their followers. Communication within the company or intra-organizational communication pertains to the level and ease of information flow between and among the members of the organization (Agarwal \& Garg, 2012). Communication is one of the principle ingredients for organizational function and growth, and without it organizations would collapse (Sophon, 2013).

Inspirational motivation is concerned with motivating employees to a higher level of contribution and productivity by dedicating attention to a higher cause and increasing followers' intrinsic motivation, commitment, and effort, which culminate in performance improvement (Barine \& Minja, 2014). Leaders with inspirational motivation are able to create a strong sense of team spirit among followers as a means of inspiring them towards the realization of stated organizational outcomes (Bass \& Riggio, 2006). Through inspirational motivation, transformational leaders communicate to organizational members' value-based visions that result in enhanced value congruence between the organization and its employees (Brown \& Trevino, 2009). This enables followers to identify more closely with the organizations goals and objectives and an alignment of their performance to that of the organization. Leaders also use inspirational motivation to sustain employee motivation towards higher productivity levels (Barrick, Thurgood, Smith\& Courtright, 2015).

Through inspirational motivation, the leaders encourage the junior level employees to communicate their ideas and opinions and in so doing enhance the amount of exchanges within the organization (Datche \& Mukulu, 2015). Furthermore, communication is perceived as occurring between equals between the leadership and the subordinate staff (Sophon, 2013). Nonetheless, Gomes (2014) found that inspirational motivation, as an aspect of transformational leadership, had zero effect on the levels of communication within the organization.

\section{Idealized Influence}

Idealized influence refers to the behaviours of a transformational leader that evokes his or her followers' trust, admiration, respect and their desires to emulate the leader. Those behaviours embody considering the wants of their followers higher than the leader's own interests or gains and demonstrating consistency and smart ethics in their conduct (Bass \& Avolio, 1994). Similarly, Jandaghi, Matin and Farjami (2009) expressed that such leaders demonstrate high standards of ethical and ethics. By therefore doing, followers would be impressed to emulate the leader, therefore raising the bar in terms of the standard of their performance at work. Previous studies have confirmed that perfect influence features a direct impact on individual performance (Bass \& Avolio, 1994).

Some literature equates idealized influence with charismatic leadership and explains that these transformational leaders act in a manner that predisposes them to be considered as role models (Gomes, 2014; Ngaithe, K'Aol, Lewa\&Ndwiga, 2016). Idealized influence has been associated with a leader who has charisma, is ethical and one who is able to effectively communicate his/her vision for the organization to subordinates (Ngaitheet al., 2016). These leaders manifest strong personal values that set them apart from the rest and establish positive images for their followers (Gomes, 2014). Transformational leadership vogue concentrates on the event of followers likewise as their wishes. Managers with transformational leadership vogue target the enlargement and development necessary system of staff, their sacred level and moralities with the preamble of their skills. The aim of transformational leadership would be to remodel people and organizations among a literal sense to vary them among the mind, insight and understanding. Reasons produce behaviour congruent with values, concepts and brings concerning changes that unit permanent, selfperpetuating and momentum building (Banjeri \& Krishnan, 2000).

Certain specific behaviours have been used to characterize idealized influence of transformational leaders. First, this group of leaders are usually great communicators of inspiring vision to followers. They are competent in communicating their vision to subordinates in ways that they can very easily understand, providing credible and sufficient information to make possible the attainment of the vision or objectives by subordinates (Avolio\&Yammarino, 2012). Secondly, these leaders have a tendency of utilizing reinforcement systems to recognize the involvement of the people they lead towards the established vision (Ngaitheet al., 2016). Through reward mechanisms, these leaders can effectively reinforce what they value and motivate employees to perform their best to realize the established vision (Gomes, 2014). Transformational leadership occurswhena leader becomes wiser and upholds the interests of the staff, once they generate awareness and acceptance for the aim and assignment of the cluster, thus once they combine staff to appear on the so much face their own self-interest for the good of the cluster. 
Perfect influence encompasses behaviours that instil pride in followers for being related to the leader typically connoted or synonymous to attractiveness. It indicates that leaders can transcend their individual self-interest for the bigger smart of the cluster and build personal sacrifices for others' profit (Awamleh \& Gardner, 1999).

Using idealized influence, transformational leaders act in a way that allows them to serve as role models to their subordinates. Bass and Riggio (2006) note that transformational leaders are admired, respected, and trusted. Their subordinates identify them with charismatic personality and attracted to emulate them. Besides, these leaders are endowed by their followers as having extraordinary capabilities, persistence and determination. Idealized leadership, at its core represents the highest levels of moral reasoning and perspective-taking capacity. These leaders are willing to sacrifice their own gain for the good of their work group and organization. They set high standards for work conduct and are a role model for those standards. They build trust in people because those who work for them know they are working toward the common good, and their sacrifices along the way are evidence of their consistency for their actions and values (Bass \& Avolio, 1994). They also are people who see the good in others first and when it is not obvious they work to build it out with concern for people. Leaders with idealized characteristics can walk first on the way they talk about.

\section{Idealized Influence and Employee Performance}

Hayati, Charkhabi and Naami (2014) carried out a study to determine the effects of transformational leadership and its components on work engagement among hospital nurses. Results showed that there is a positive and significant effect of transformational leadership on work engagement and its aspects. Idealized influence among the leaders was found to result in forming a particular belief among members of staff toward those leaders and hence leaders can easily transmit their inspirational motivation to them. As a result, idealized influence sets high standards and creates a positive vision which challenges the employees and establishes enthusiasm together with optimism for attaining success in work. The study recommends that leaders and managers should be helped in developing what is exists about leadership and relate this to the ideal qualities that develop leadership behaviour that is effective and active.

Mbithi, Obonyo and Munyoki (2014) conducted a study to understand how universities in Kenya responded to reforms, focusing on their leadership which is critical in both managing the transformation and creating academic excellence. It emerged that transformational leadership behaviour of the top leadership of universities in Kenya led to high employee and employee performance and that the top leadership of these universities is able to match their strategy with the correct structure, systems and technology to achieve organizational effectiveness. Idealized influence has been associated with a leader who has charisma, is ethical and one who is able to effectively communicate his/her vision for the organization to subordinates (Ngaitheet al., 2016). These leaders manifest strong personal values that set them apart from the rest and establish positive images for their followers (Gomes, 2014).

Articulating an appealing and inspiring vision, goal setting and role modelling are effective leadership practices related to idealized influence that leaders apply to drive performance improvement beyond contractual expectations (Wang, Tsui\& Xin, 2011). Transformation alleaders are able to define and articulate a vision for the organization, and inspire followers to carry it out. A CEO's charisma is related to organization performance via its effect on two important mediators; raising the leadership climate within the organization and increasing the organizational identity strength which in turn, relates positively to performance outcomes and effectiveness. (Epitropaki, Kark, Mainemelis\& Lord, 2017).

Self-efficacy is outlined by Bandura (1997) as the assurance or confidence a people have on their capability to arrange and execute actions needed to finish a task. The larger one's self-efficacy is in reference to a particular activity, the larger their participation and perseverance in attaining it (Cavazotte et al., 2013). Bandura (1986) asserts that four components within the social context will have an effect on self-efficacy particularly past achievements, observation of others, verbal persuasion, and emotion. Articulating the significance of the task one has completed, encouraging contribution in call processes, and provoking self-assurance that performance are going to be high square measure leadership behaviours related to idealized influence views (Cavazotte, Moreno \& Bernardo, 2013). Idealized influence is an important element of transformational leadership that has a direct effect on the level of employee engagement in their work and the organization. Idealized influence, according to Hayati et al. (2014) is a requisite ingredient in achieving employee engagement and has a general positive outcome on employee performance.

Cohesion is another crucial component for effectiveness of a team. Dionne et al. (2004) observe that previous studies have establish that teamwork operations such as conflict management and cohesion enhance team performance. Idealized influence impacts cohesion through rapport building and empathetic language (Cavazotte, Moreno \&Bernardo, 2013). Furthermore, leaders can inspire followers to adopt a team-oriented approach in performing their tasks by team building and establishing goals for teams (Krishna, 2011). 
Kyrgidou and Spyropoulou (2013) acknowledge that performance management has a critical role in enhancing performance in individuals by offering feedback, defining goals and accomplishing them. Dirisuet al. (2013) also note that performance contributes to growth and success of the organization, with a focus on combining competencies and expertise of employees with organizational goals and objectives. Shadraconis (2013) observed that there is a critical relationship between employees' performance and leadership style. It is noted that employees who believe that they are respected and treated respectfully by their employers are more likely to be better performers in their respective jobs due to their positive motivation that leads to their loyalty to their organizations.

In a study conducted by Sosik, Godshalk and Yammarino (2004), it was found that idealized influence had a direct positive influence on encouraging employees to achieve the set goals and objectives. The same study found that such leaders reduced the level of negative stressors that their employees experience in relation to their work, and increased their level of performance of their assigned duties. Idealized influence encourages employees and protégés to develop and learn, permitting them to develop self-identity, self-confidence and well-being, which increases employee engagement in their jobs. Idealized influence is an important element of transformational leadership that has a direct effect on the level of employee engagement in their work and the organization (Kark \& Chen, 2013). Idealized influence, according to Hayati et al. (2014), is a requisite ingredient in achieving employee engagement and has a general positive outcome on employee performance. Transformational leaders with idealized influence or charisma establish a personal relationship with their followers. They constantly and persistently attend to the welfare of employees by being sensitive to their contribution to the planning process (Avolio \& Yammarino, 2012). The outcome of this attention is that the employees develop a greater sense of commitment, engagement or involvement in the organizational processes, and in their jobs (Kark \& Chen, 2013).

\section{Statement of the Problem}

Any extraordinary action or success accomplished by a leader occurs with the active involvement and support of someone else. Leadership is not a one-person act; it is a team effort of the leader and his followers. Collaboration between the two parties is, therefore, essential ability for achieving and sustaining high performance (Kouzes \& Posner, 2014). Leaders have to be compelled to take a pro-active role in making a positive context and organization for cooperation and collaboration. A leader has to assign tasks to each team member in order that he contributes to a singular task for the ultimate outcome to succeed.

One of the reasons that reduce organizational or institutional effectiveness and productivity is the low level of organizational commitment. Studies demonstrated that in the case of low level of organizational commitment, organizational trust decreases (Yilmaz, 2008). The effectiveness of an organization's management can critically impact upon its viability and there are many reasons why the management process may fail and include failure to think creatively about the likely effects of plans, obtain external/internal participation and commitment, co-ordinate and control resources (Ngware \& Koross, 2009). Previous studies have shown that transformational leaders in different settings are regarded as being more effective, higher performers, more promotable and more interpersonally sensitive (Rubin, Munz\& Bommer, 2005). All these outcomes ultimately contribute towards effective organization performance, meeting stakeholder needs and customer satisfaction.

Empirical evidence also shows that transformational leadership is strongly correlated with employee work outcomes such as lower turnover rates, higher level of productivity, employee satisfaction, creativity, goal attainment and follower well-being (Eisenbeib \& Boerner, 2013). Fundamental research on transformational leadership on employee performance has been conducted widely worldwide as well as in some Organizations in Kenya. While these studies provide the influences of transformational leadership on employee performance, a gap exists on how individual component factors of transformational leadership influence employee performance. The research that informed this paper sought to fill this gap by taking Moi Teaching and Referral Hospital as a case study. MTRH is the second largest public hospital in Kenya. Its success story needs to be told. It is, however, important to state that this story is incomplete without knowing the contributions of transformational leadership on the Employee's performance. Therefore, this paper examines the influence of two aspects of transformational leadership, namely inspirational transformation and idealized influence, on the performance of employees at MTRH.

\section{Materials and Methods}

This study adopted a descriptive research design. The descriptive analysis approach was chosen for the study because it seeks to gain insight into a phenomenon as a means of providing basic information in an area of study (McDaniel \& Gates, 2001). It was based on the conceptual relationship between the independent variable and the dependent variable. The target population for the study comprised all the staff of MTRH. At the time of study, the hospital had 18 top level managers, 110 middle level management staff and 3611 support staff. 
The Sampling Frame used in the study was the Staff Establishment Dashboard for MTRH which was available at the Human Resource and Capacity Development Directorate. The inclusion criterion was all MTRH staff on permanent and pensionable terms of employment. The exclusion criterion was staff who were on terminal leave, study leave or suspension.

This study employed stratified random sampling method. The first stratum was made up of Strategic Level Managers including Directors and Managers; Second Stratum was composed of Middle Level Managers whereas the third Stratum included Operational Staff. Simple Random Sampling through Random Integer Generator Software was be used in each of the Stratum to recruit respondents to participate in the study. This ensured that every employee had an equal chance of participating in the study across all the tiers of the Hospital. The sample size was calculated using Taro Yamane's formula (Yamane, 1967). The formula yielded a total of 463 respondents comprising 17 senior managers (strategic level), 86 middle level managers (tactical level) and 360 support staff (operational level).

Primary data was collected through self-administered structured questionnaire on a Likert scale. The data collected was stored in appropriate format that permits statistical analysis. The analysis entailed computer-aided, statistical manipulation. All the data collected was entered into the statistical package and data cleaned for missing values and data entry errors. Data analysis was done using STATA/MP Version 13. Quantitative data was analysed to generate descriptive statistics which include frequency, percentages and means to profile sample characteristics and major patterns emerging from the data. Inferential statistics was applied to check whether there was linear relationship between the variables and powered to $95 \%$ confidence interval.

\section{Results}

\section{Influence of Inspirational Motivation on Employee Performance}

The study investigated the influence of inspirational motivation on employee performance at MTRH. The findings were as summarised in Table 1 below.

Table 1: Influence of Inspirational Motivation on Employee Performance

\begin{tabular}{clcccc}
\hline S. No & Measured Parameters: Supervisor & Mean & SD & Min & Max \\
\hline 1 & Motivates of employees to high productivity & 4.47 & 0.64 & 3 & 5 \\
2 & Ensure clear conveyance of messages to employees & 4.43 & 0.66 & 2 & 5 \\
3 & Articulates a compelling vision for the future & 4.40 & 0.64 & 2 & 5 \\
4 & Is able to ensure continued optimism and enthusiasm & 4.34 & 0.52 & 3 & 5 \\
5 & Provides continuous encouragement & 4.33 & 0.57 & 2 & 5 \\
6 & Shows determination to accomplish what he/she sets out to do & 4.22 & 0.72 & 1 & 5 \\
7 & Is able to inspire confidence to the employees & 4.16 & 0.76 & 1 & 5 \\
8 & Talks enthusiastically about what needs to be accomplished & 4.13 & 0.61 & 2 & 5 \\
Total & Overall Inspirational Motivation & $\mathbf{4 . 3 1}$ & $\mathbf{0 . 4 0}$ & $\mathbf{2 . 8 7}$ & $\mathbf{5}$ \\
\hline
\end{tabular}

Influence of Idealized Influence Stimulation on Employee Performance

The study also sought to determine the influence of idealized influence on employee performance at MTRH. Table 2 below presents the research results on the influence of idealized influence stimulation on employee performance.

Table 2: Influence of Idealized Influence on Employee Performance

\begin{tabular}{|c|c|c|c|c|c|}
\hline S. No & Measured Parameters: Supervisor & Mean & SD & Min & Max \\
\hline 1 & Articulates an appealing and inspiring vision and goals & 4.53 & 0.56 & 3 & 5 \\
\hline 2 & Motivates Employees to believe on our abilities & 4.44 & 0.59 & 2 & 5 \\
\hline 3 & $\begin{array}{l}\text { Is a good role model in influencing high quality of service } \\
\text { among employees }\end{array}$ & 4.35 & 0.73 & 2 & 5 \\
\hline 4 & Encourages participation of employees in decision making & 4.33 & 0.67 & 2 & 5 \\
\hline 5 & Enables efficient utilization of available resources & 4.26 & 0.56 & 2 & 5 \\
\hline 6 & $\begin{array}{l}\text { Emphasizes the importance of employee learning and } \\
\text { development }\end{array}$ & 4.25 & 0.68 & 2 & 5 \\
\hline 7 & Talks to us about interpersonal relations and team cohesion & 4.22 & 0.57 & 2 & 5 \\
\hline 8 & $\begin{array}{l}\text { Is able to take risks towards attainment of Organizational } \\
\text { Goals }\end{array}$ & 4.14 & 0.63 & 2 & 5 \\
\hline Total & Overall Idealized Influence & 4.31 & 0.37 & 2.62 & 5 \\
\hline
\end{tabular}


As indicated in the table above, "I am proud to be associated with my Supervisor" was rated highest with a mean score of 4.53 (SD 0.56) followed by "performance requirements are designed according to the organization's needs" having a mean score of 4.44(SD 0.59).

"Supervisor is a good role model in influencing high quality of service among employees" was rated with a mean of 4.35 (SD 0.73) whereas "Encourages participation of employees in decision making" was rated at 4.33 (SD 0.67). The least mean score (M4.14 SD 0.63) was observed in "Supervisor able to take risks towards attainment of Organizational Goals". The overall mean score for idealized influence was 4.31 (SD 0.37) and a range of 2.62 to 5 .

\section{Correlation Analysis}

Among the parameters of transformation leadership that were measured in the study, inspirational motivation $(\mathrm{M}=$ 4.31, $\mathrm{SD}=0.40)$ had the strongest positive correlation with employee performance $(\mathrm{M}=4.22, \mathrm{SD}=0.33), \mathrm{r}=.476, \mathrm{p}<$ $0.001)$. Idealized influence was $(\mathrm{M}=4.31, \mathrm{SD}=0.37)$ also positively correlated with employee performance $(\mathrm{M}=$ $4.22, \mathrm{SD}=0.33), \mathrm{r}=.435, \mathrm{p}<0.001$. Therefore, inspirational motivation and idealized influence, as the parameters of transformation leadership, were positively correlated with employees' performance. These results were as summarized in Table 3 below.

Table 3: Correlation between Transformational Leadership \& Employee Performance

\begin{tabular}{llccc}
\hline Variables & Statistic & $\begin{array}{c}\text { Inspirational } \\
\text { Motivation }\end{array}$ & $\begin{array}{c}\text { Idealized } \\
\text { Influence }\end{array}$ & $\begin{array}{c}\text { Employee } \\
\text { Performance }\end{array}$ \\
\hline Inspirational & $\mathrm{r}$ & 1 & & \\
Motivation & $\mathrm{p}$-value & - & & \\
Idealized & $\mathrm{n}$ & 448 & 1 & \\
Influence & $\mathrm{r}$ & 0.624 & - & \\
& $\mathrm{p}$-value & $<0.001$ & 448 & \\
Employee & $\mathrm{n}$ & 448 & 0.435 & 1 \\
Performance & $\mathrm{r}$ & 0.476 & $<0.001$ & - \\
& $\mathrm{p}$-value & $<0.001$ & 448 & 448 \\
\hline
\end{tabular}

\section{Discussion}

\section{Inspirational Motivation on Employee Performance}

The study found that supervisors ensure clear conveyance of messages to employees. This concurred with the findings of Mpungu (2009) that that for organizations to be performing highly, effective communication that involve employees in decision making should be adopted and bureaucratic tendencies must be avoided, and that leaders should avail necessary information to their followers. The results also agreed with those of Sophon (2013) who contends that, transformational leadership facilitates communication among employees and between the leadership and the employees. The research also established that leaders in the organizations assign employees with tasks, which they are most comfortable doing which is in agreement with Long et al. (2014) who observed that leaders are able to assign employees tasks which they are most comfortable doing. Further, Gomes (2014) states that transformational leaders communicate high expectations that followers want to achieve. Such leaders inspire the followers, promote team spirit, enthusiasm, and optimism among them. In addition, Rajhans (2012) investigated the link between communication and motivation and its overall impact on the staff performance using an empirical review. The results showed that organizational communication plays an important role in employee motivation and performance of staff. The study recommended that there has to be upward and downward communication in an organization so that creative suggestions from the staff are used to assist management in decision-making and improvement of the company

As indicated in the research, supervisors at MTRH also motivate employees to higher levels of productivity. These findings agreed with those of BarineandMinja (2014) that inspirational motivation is concerned with motivating employees to a higher level of contribution and productivity by dedicating attention to a higher cause and increasing followers' intrinsic motivation, commitment, and effort, which culminate in performance improvement. Bass andRiggio (2006) also indicate that inspirational leaders are able to create a strong sense of team spirit among followers as a means of inspiring them towards the realization of stated organizational outcomes. 
The finding also concurs with Brown and Trevino (2009) that through inspirational motivation, transformational leaders communicate to organizational members' value-based visions that result in enhanced value congruence between the organization and its employees which enables followers to identify more closely with the organizations goals and objectives and an alignment of their performance to that of the organization.

Another finding of the study was that supervisors articulates a compelling vision for the future. This finding reiterates that of Brown and Trevino (2009) who note that transformational leaders communicate to organizational members' value-based visions that result in enhanced value congruence between the organization and its employees. This enables followers to identify more closely with the organizations goals and objectives and an alignment of their performance to that of the organization. The results are in agreement with Hayatiet al. (2014) who observe that, transformational leaders draw a strict and positive view of the future for their subordinates and stimulate them to go towards organizational aims and mission, while encouraging their followers to become part of the overall organizational culture and environment.

It also emerged that supervisors provide continuous improvement and able to ensure continued optimism and enthusiasm. The results are in agreement with what Datche and Mukulu (2015) have observed that, through inspirational motivation, leaders encourage employees to communicate their ideas and opinions and in so doing enhance the amount of exchanges within the organization. Such leaders motivate employees within the entire organization and provide incentives that drive the employees to work harder to achieve the predetermined organizational goals.

\section{Idealized Influence on Employee Performance}

The Supervisor articulates an inspiring vision and role modelling to influence high quality of service. This concurs with the views of Epitropakietal. (2017) that transformationalleadersare able to define and articulate a vision for the organization, and inspire followers to carry it out. A CEO's charisma is related to organizational performance via its effect on two important mediators; raising the leadership climate within the organization and increasing the organizational identity strength which in turn, relates positively to performance outcomes and effectiveness. Ngaitheet al. (2016) also observe that a leader who has charisma is able to effectively communicate his/her vision for the organization to subordinates effectively, and that transformational leaders have a tendency of utilizing reinforcement systems or mechanisms to recognize the involvement of the people they lead in achieving the vision that they have established and communicated.

It was also found that leaders motivate employees to believe on their abilities. This concurs with the observation by Bandura (1986) that verbal persuasion improves self-efficacy and emotional state of individuals. Gomes (2014) also contends that idealized influence leaders have a direct effect on the level of employee engagement in their work and in the organization. Leaders are able to take risks to attain Institution's Goals. Furthermore, Gomes notes that, a transformational leader is willing to take risks towards the attainment of organizational goals or personal objectives. It was also found that the MTRH leaders encourage participation of employees in decision-making. The results agreedwith Al-Tarawneh's (2012) that, the process of decision-making takes place at all levels of the organization, and it involves problem identification and the consideration of multiple alternatives. Further, Elgelal (2014) refers to the process by which employees' perceptions of their self-efficacy are intensified through stimulating participation in decision processes, and through articulating the importance of the work one has done.

The study found that supervisors also enable efficient utilization of available resources and emphasizes on the importance of employee learning and development. The results are in agreement with Kyrgidou and Spyropoulou (2013) who state that, employee performance is the successful completion of tasks by a selected individual or individuals to pre-defined acceptable standards while efficiently and effectively utilizing available resource, and that performance management plays an important role in enhancing employee performance by providing feedback, setting goals and achieving them. Further, Gomes (2014) argues that, idealized influence leaders encourage employees and protégés to develop and learn, permitting them to develop self-identity, self-confidence and well-being. Lastly, it was established that the supervisor talk about interpersonal relations and team cohesiveness. This concurs with Cavazotte $e t$ al. (2013) who state that idealized influence leaders could positively impact team interpersonal processes through their outcomes, and that leaders impact cohesion through visioning behaviours involving rapport building and empathetic language.

\section{Conclusion}

As evidenced by the study of MTRH, Supervisors motivate employees to high productivity and facilitate clear conveyance of messages to employees, which has encouraged junior level employees to communicate their ideas and opinions. The leaders provide staff with a vision for the future and ensures continued optimism and enthusiasm. 
The study concludes that leaders provided opportunities for continual improvement. Moreover, the study concludes that the Supervisors articulated an appealing and inspiring vision and goals as well as motivates employees to believe on their abilities. Lastly, the study also concludes that Supervisors are good role models in influencing high quality of service delivery and at the same time encourage participation of employees in decision-making.

\section{Recommendations}

The study recommends that leaders should express more enthusiasm to staff on what needs to be accomplished and continuously provide employees with an inspiring vision and mission to increase employee efforts in meeting and achieving set organizational goals and objectives. Further, the study recommends that Supervisors should to take risks to attain organizational goals through encouraging and emphasizing on employees learning and development. Supervisors should also talk about interpersonal relations, team cohesion as well as enabling decision-making at all levels of the organization, be sensitive to individual employees' needs, and take into consideration multiple alternatives when making decisions. Further, the study recommends that Organizations should utilize available resources efficiently and employees continually provided with feedback on their performance.

\section{References}

Agarwal, S., \& Garg, A. (2012). The Importance of Communication within Organizations: A Research on Two Hotels in Uttarakhand. IQSR Jornal of Business and Management, 3(2), 40-49.

Ahmad, F., Abbas, T., Latif, S., \& Rasheed, A. (2014). Impact of Transformational Leadership on Employee Motivation in Telecommunication Sector. Journal of Management Policies and Practices, 2(2), 11-25.

Al-Tarawneh. (2012). The Main Factors beyond Decision Making. Journal of Management and Research, 4(1), 1-23.

Avolio, B., \& Yammarino, F. (2012). Transformational and Charismatic Leadership: The Road Ahead. (Eds.). Oxford,UK: JAI Elsevier.

Awamleh, R., \& Gardner, W. (1999). Perceptions of leader charisma and effectiveness: The effects of vision content, delivery, and employee performance. The Leadership Quarterly, 10(3), 345-373.

Bandura, A. (1986). Social foundation of thought and action: a social cognitive theory. Englewood Cliffs, NJ: Prentice Hall.

Bandura, A. (1997). Self-efficacy: the exercise of control. New York, NY: W.H. Freeman.

Banjeri, P., \& Krishnan, V. (2000). Ethical preferences of transformational leaders: An empirical investigation. Leadership and Organizational Development Journal, 21(8), 405-413.

Barine, K., \& Minja, D. (2014). Transformational Corporate Leadership. New York: Intergrity Publishing.

Barrick, M., Thurgood, G., Smith, T., \& Courtright, S. (2015). Collective Organizational Engagement: Linking Motivational Antecendents, Strategic Implementation and Firm Performance. Academy of Management Journal, 58(1), 111-135.

Bass, B. (1985). Leadership and Performance Beyond Expectations. New York: Free Press.

Bass, B., \& Avolio, B. (1994). Transformational Leadership and Organizational Culture. International Journal of Public Administration, 17(3), 541-554.

Bass, B., \& Riggio, R. (2006). Transformational Leadership 2nd Ed. Mahwah,NJ: Lawrence Erlbaum Associates Inc.

Brown, M., \& Trevino, L. (2009). Leader-Follower Values Congruence: Are Socialized Charismatic Leaders better able to achieve it? Journal of Applied Psychology, 94(2), 478.

Cavazotte, F., Moreno, V., \& Bernardo, J. (2013). Transformational Leaders and Work Performance: The Mediating Roles of Identification and Self-Efficacy. Journal of Management and Economics, 56-77.

Crompton, B. (2012). The effect of business coaching and mentoring on small to medium enterprise performance and growth. Manuscript submitted for publication.

Datche, A., \& Mukulu, E. (2015). The Effects of Transformational Leadership on Employee Engagement: A Survey of Civil Service in Kenya. Issues in Business Management and Economics, 3(1), 9-16.

Dionne, S., Yammarino, F., Atwater, D., \& Spangler, W. (2004). Transformational leadership and team performance. Journal of Organizational Management, 17(2), 177-193.

Dirisu, J., Iyiona, O., \& Ibidunni, O. (2013). Product Differentiation: A Tool of Competitive Advantage Optimal Organizational Performance (A Study of Uniliver Nigeria PLC). European Scientific Journal, 9(34), 258-281.

Eisenbeib, S., \& Boerner, S. (2013). A Double-edged Sword: Transformational Leadership and Individual. British Journal of Management, 24(1), 54-68.

Elgelal, K. (2014). The Influences of Transformational Leaderships on Employees Performance (A Study of the Economics and Business Faculty Employee at University of Muhammadiyah Malang. Asia Pacific Application, 3(1), 48-66. 
Epitropaki, O., Kark, R., Mainemelis, C., \& Lord, R. (2017). Leadership and Followership Identity Processes: A Multilevel Review. The Leadership Quarterly, 28(1), 104-129.

Gomes, A. (2014). Transformational Leadership: Theory, Research and Application to Sports. New York,NY: Nova Science Publishers.

Hayati, D., Charkhabi, M., \& Naami, A. (2014). The relationship between transformational leadership and work engagement in governmental hospitals nurses: a survey study. SpringerPlus, 3(25).

Jandaghi, G., Matin, H., \& Farjami, A. (2015). Comparing Transformational Leadership in Successful and Unsuccessful Companies. The Journal of International Social Research, 2(6), 357-372.

Kark, R., B., S., \& Chen, G. (2013). The Two Faces of Transformational Leadership: Empowerment and Dependency. Journal of Applied Psychology, 88(2), 246-255.

Kehinde, O., \& Banjo, H. (2014). A Test of the Impact of Leadership Styles on Employee Performance: A Study of Department of Petroleum Resources. International Journal of Management Science, 2(3), 149-160.

Kent, T., Crotts, J., \& Azziz, A. (2001). Four factors of transformational leadership behavior. Leadership and Organizational Development Journal, 22(5), 221-229.

Krishna, Y. (2011). Effects of Transformational Leadership on Team Performance. International Journal of Business Management and Economic Research, 2(1), 152-157.

Kyrgidou, L. P.,\&Spyropoulou, S.(2013). Driver and performance outcomes of innovativeness: An empirical study.British Journal of Management, 24, 281-298.

Long, C., Yusof, W., Kowang, T., \& Heng, L. (2014). The Impact of Transformational Leadership Style on Job Satisfaction. World Applied Science Journal, 29(1), 117-124.

Mbithi, A., Obonyo, P., \& Munyoki, J. (2014). Transformational Leadership and Performance of Universities in Kenya. International Journal of Science and Education, 134-158.

McDaniel, C., \& Gates, R. (2001). Marketing Research Essentials. OH:South Western College: Cincinnati.

Mpungu, B. (2009). The effect of communication on workers' performance in organizations: A case of Mobile Telephone Network (MTN) Kampala.

Ndisya, S., \& Juma, D. (2016). Influence of Transformational Leadership on Employee Performance. A Case Study of Safaricom Limited. Strategic Journal of Business and Change Management, 3(2).

Ngaithe, L., K'Aol, G., Lewa, P., \& Ndwiga, M. (2016). Effect of Idealized Influence and Inspirational Motivation on Staff Performance in State Owned Enterprises in Kenya. European Journal of Business and Management, $8(30), 6-13$.

Ngware, M., \& Koross, P. (2009). Principals' and students' perceptions on parental contribution to financial management in secondary schools in Kenya. Quality Assurance in Education, 17(1), 61-78.

Rajhans, K. (2012). Effective organizational communication: A key to employee motivation and performance. Interscience Management Review, 2(2), 81-85.

Rubin, R., Munz, D., \& Bommer, W. (2005). Leading from Within: effects of Emotional Recognition and Personality on transformational Leadership Behavior. Academy of Management Journal, 845-858.

Salanova, A., \& Kirmanen, S. (2010). Employee Satisfaction and Work Motivation: Theories, Research, Findings. LAP Lambert Acad. Publ., .

Shadraconis, S. (2013). Organizational Leadership in Times of Uncertainty: Is Transformational Leadership the Answer. A Journal of Transdisciplinary Writing and Research from Claremont Graduate University, 2(1), 2829.

Sophon, S. (2013). Organizational Leadership in Times of Uncertainty: Is Transformational Leadership the Answer? A Journal of Transdisciplinary Writing and Research from Claremont Graduate University, 2(1), 1-16.

Sosik, J., Godshalk, V., \& Yammarino, F. (2004). Transformational leadership, learning goal orientation, and expectations for career success in mentor - protégé relationships: A multiple levels of analysis perspective. The Leadership Quarterly, 15, 241-261.

Wang, H., Tsui, A., \& Xin, K. (2011). CEO Leadership Behaviors, Organizational Performance, and Employees' Attitudes. The Leadership Quarterly, 22, 92-105.

Yamane, T. (1967). Statistics, An Introductory (2nd Edition ed.). New York: Harper \& Row.

Yilmaz, K. (2008). The Relationship between Organizational Trust and Organizational Committment in Turkish Primary Schools. Journal of Applied Sciences, 8(12), 2293-2299.

Yukl, G. (2002). Leadership in Organizations (5th ed). Englewood Cliffs,NJ: Prentice Hall. 